\title{
Effect of tillage and nutrient management on seed cotton yield, yield contributing characters and total uptake by cotton
}

\author{
N. S. WAGH, R. N. KATKAR AND V. K. KHARCHE
}

Received : 25.09.2016; Revised : 18.10.2016; Accepted : 13.11.2016

MEMBERS OF RESEARCH FORUM:

Corresponding author :

N.S. WAGH, Department of Soil Science and Agricultural Chemistry, Dr. Panjabrao Deshmukh Krishi Vidyapeeth, AKOLA (M.S.) INDIA

Co-authors :

R. N. KATKAR AND V. K.

KHARCHE, Department of Soil Science and Agricultural Chemistry, Dr. Panjabrao Deshmukh Krishi Vidyapeeth, AKOLA (M.S.) INDIA

\section{Summary}

The field experiment was conducted at the Research farm, Department of Soil Science and Agricultural Chemistry, Dr. Panjabrao Deshmukh Krishi Vidyapeeth, Akola to study the effect of integrated nutrient management on soil quality and cotton productivity under different tillage practices in vertisol. The treatments thus involved two main treatments and eight sub treatments. The experiment main plot comprised of two treatments i.e. conservation tillage (CNS) and CNV. In which one harrowing and two weeding and in conventional tillage (CNV) one ploughing and one harrowing, two hoeing and two hand weeding operations were carried out in eight sub plot treatments of nutrient management. The seed cotton yield was slightly higher under conservation tillage as compared to conventional tillage. Highest seed cotton yield was recorded in the treatment receiving $100 \% \mathrm{RDF}\left(60: 30: 30 \mathrm{NPK} \mathrm{kg} \mathrm{ha}^{-1}\left(15.57 \mathrm{q} \mathrm{ha}^{-1}\right)\right.$ followed by $50 \%$ RDF $+50 \% \mathrm{~N}(\mathrm{FYM})\left(14.84 \mathrm{q} \mathrm{ha}^{-1}\right)$.Significantly highest bolls per plant in conservation tillage ( 19.95 bolls per plant) than in CNV ( 17.51 bolls per plant) while bolls per plant was recorded in the treatment receiving $100 \% \mathrm{RDF}$ (60:30:30 NPK kg ha ${ }^{-1}(20.38$ bolls per plant) followed by $50 \% \mathrm{RDF}+50 \% \mathrm{~N}(\mathrm{FYM})\left(\mathrm{T}_{3}\right)$ ( 19.47 bolls per plant).Significantly higher uptake of major and micronutrients was recorded under conservation over conventional tillage. Significantly higher content of macronutrients viz., N, P, K, S and Mg were recorded in the treatment receiving $100 \% \mathrm{RDF}\left(60: 30: 30 \mathrm{NPK} \mathrm{kg} \mathrm{ha}^{-1}\right)$ followed by $50 \% \mathrm{RDF}+50 \% \mathrm{~N}$ (FYM). The total uptake of macronutrients at boll development stage was found to be significantly higher in the treatment receiving $100 \% \mathrm{RDF}\left(60: 30: 30 \mathrm{NPK} \mathrm{kg} \mathrm{ha}^{-1}\right)$ followed by $50 \% \mathrm{RDF}+50 \% \mathrm{~N}(\mathrm{FYM})$. It was also noticed that the total uptake of nutrients increased from square initiation to boll development stage as the age of the crop advances towards maturity.

Key words : Conservation tillage, Yield, Uptake, Nutrient management

How to cite this article : Wagh, N.S., Katkar, R.N. and Kharche, V.K. (2016). Effect of tillage and nutrient management on seed cotton yield, yield contributing characters and total uptake by cotton. Asian J. Soil Sci., 11 (2) : 277-285 : DOI : 10.15740/HAS/AJSS/11.2/277-285. 